\title{
SHORT-TERM PROGNOSIS FOR SPEECH AND LANGUAGE IN FIRST STROKE PATIENTS
}

\author{
Fabricio F. Oliveira', Benito P. Damasceno ${ }^{2}$
}

\begin{abstract}
Objective: To evaluate the factors that can influence evolution of communication after a first stroke. Method: Thirty-seven adult patients were evaluated for speech and language within 72 hours after a single first-ever ischemic brain injury and later on. Patients who were comatose, with decompensated systemic diseases, or history of chronic alcoholism or illicit drug use were not included. Brain CT and/or 2T-MR exams were solicited for topographic correlation. Size of infarct was classified as large or small according to the TOAST classification. Results: Patients who survived had lesser chances of presenting with aphasia or dysarthria 3 months after the stroke if the infarct size was small ( $p=0.017)$. Gender, age, schooling, aphasia subtype, infarct side and topography were non-significant in our sample. Subjects with global aphasia or lone cortical dysarthria had a slower evolution. Conclusion: Brain injury size was the most influential factor for neurological outcome at 3 months post-stroke.
\end{abstract}

KEY WORDS: linguistics, stroke, brain infarction, language, speech, disability evaluation, prognosis.

\section{Prognóstico em curto prazo para fala e linguagem em pacientes acometidos de infarto cerebral único}

Resumo - Objetivo: Avaliar os fatores que podem influenciar o desempenho neurolinguístico após um primeiro acidente vascular cerebral isquêmico. Método: Foram avaliados 37 pacientes quanto a fala e linguagem dentro de 72 horas após um primeiro infarto cerebral e posteriormente. Pacientes comatosos, com doenças sistêmicas descompensadas, história de etilismo crônico ou uso de drogas ilícitas não foram incluídos. TC e/ou RMN-2T cerebrais foram solicitadas para correlação topográfica. Utilizou-se a classificação TOAST para o tamanho do infarto (grande ou pequeno). Resultados: Sobreviventes tiveram menores chances de apresentarem-se afásicos ou disártricos 3 meses após o evento agudo caso o infarto fosse pequeno ( $p=0.017$ ). Gênero, idade, escolaridade, subtipo de afasia, lado e topografia da lesão cerebral não foram fatores estatisticamente significativos. Pacientes portadores de afasia global ou disartria cortical isolada evoluíram mais lentamente. Conclusão: $O$ tamanho da lesão cerebral foi o fator mais influente para o desempenho neurolinguístico 3 meses após o evento agudo.

PALAVRAS-CHAVE: linguística, acidente cerebral vascular, infarto encefálico, linguagem, fala, avaliação da deficiência, prognóstico.

Recovery from vascular aphasia implies functional reorganization of the language systems in the brain through neuroplasticity mechanisms that seem to involve both the damaged and the contralateral hemispheres ${ }^{1,2}$. However, the time course of these phenomena is variable for every patient. In general, recovery is usually faster in the first months post-stroke, more importantly for fluency than for speech comprehension ${ }^{3,4}$, an unwanted result considering that compromised comprehension in the acute stroke patient usually leads to a longer hospital stay ${ }^{5}$. We have reason to believe in a tendency for language recovery to accompany motor recovery, which is in accordance with phylogenetical studies that demonstrate a simultaneous development of verbal and gesture expression with facial movements and hand skills ${ }^{6}$.

Prognostic indicators are considerably important for clinical management. Several quality-of-life scales ${ }^{7,8}$ and clinical outcome predictors ${ }^{5,9,10}$ are available for stroke patients, but they usually lack the necessary sensitivity for aphasia or dysarthria time-span evaluation. This is of

Department of Neurology, State University of Campinas, UNICAMP, Campinas SP, Brazil: ${ }^{1}$ MD, MSc; ${ }^{2} \mathrm{MD}, \mathrm{MSc}$, PhD, Full Professor and Head of the Department of Neurology. This study was sponsored by CAPES (Coordenação de Aperfeiçoamento de Pessoal de Nivel Superior), Brazil. 
relevance regarding the deed of stroke being the leading cause of aphasia".

Very few studies are available that correlate poststroke speech and language evolution with brain injury characteristics ${ }^{12,13}$, less so if we consider the evaluation of patients who have suffered a first-ever stroke. This analysis turns out to be even more complicated by taking into account the fact that different types of aphasia tend to recover at different rates and to a different degree ${ }^{3}$. Even though injury location is usually of no use for prediction of outcome ${ }^{12}$, injury size can demonstrate an important predictive value for post-stroke speech and language evolution. Stroke patients and their families are usually very anxious about the recovery of function, but health care teams are seldom capable of precisely establishing aims in terms of neurological rehabilitation. Prognosis for cerebrovascular disorders of speech and language is not well established, mainly because of the scarceness of objective data in this regard.

This study was conducted to evaluate the factors that can influence the evolution of communication after a first stroke.

\section{METHOD}

This is a prospective and non-randomized study conducted at the Hospital das Clínicas - UNICAMP, initially with the enrollment of patients from the Emergency Unit. During a period of 12 months (between May 2007 and April 2008), 37 adult patients ( 22 male, 15 female) were evaluated for speech and language disorders within 72 hours after a single first-ever ischemic brain injury. Patients who were comatose, with decompensated systemic diseases, or a history of chronic alcoholism or illicit drug use were not included. Brain CT and/or 2T-MR exams were solicited for topographic correlation with the brain injury site, both in the acute (CT) and in the chronic phases (2T-MR or CT at an average of 3 months post-stroke).

The following factors were considered for prognostic analysis in this study: gender (male, female), age, schooling, type of speech or language disorder, lesion side (left, right), infarct size (large, small) and brain injury topography in the categories of specific sites (frontal lobe, temporal-parietal lobes, capsulenuclear, and full middle cerebral artery territory) and structural organization (cortical-subcortical, cortical alone or subcortical alone). Size of infarct was classified as large (more than $1.5 \mathrm{~cm}$ in diameter on CT or MR at any plane) or small (less than $1.5 \mathrm{~cm}$ in diameter on CT or MR at all planes), in accordance with the TOAST (Trial of Org 10172 in Acute Stroke Treatment) ${ }^{14}$ classification. Parietal lesions were not accounted for in the category of injured lobes because they consisted on a small group (only 3 patients) of non-aphasics. In regard to subcortical lesions, we considered those patients who had radiological confirmation of injuries that included the periventricular white matter, thalamus, internal capsule, globus pallidus, caudate nucleus or lentiform nucleus.

Neurological evaluation was conducted in the Portuguese language, according to the following internationally accepted directives ${ }^{4}$ :

(1) A brief history of the acute symptoms had to be reported by the patient or a relative, including data on cardiovascular risk factors and socio-educational information;

(2) Patients were assessed for consciousness level, behavioral disturbances, presence or absence of hemiparesis, hypoesthesia, unilateral neglect, hemianopias or quadrantanopias, hearing impairment and visual acuity;

(3) They were then tested for attentional deficits by means of the "A" Random Letter Test ${ }^{15}$, in which they had to tap the unimpaired hand on the desk immediately after hearing the letter "A" (75 letters were randomly presented orally by the examiner, 20 of them were "A" letters);

(4) Hand dominance was assessed according to a 5-point scale of the Edinburgh Inventory ${ }^{16}$ (stronger right-hand preference, weaker right-hand preference, indifferent, weaker lefthand preference, stronger left-hand preference) for performance in simple tasks - writing, tooth-brushing, catching a spoon, opening a box, drawing, knife-cutting, sweeping the floor (upper hand position on the broomstick), object-throwing, scissor-cutting, and lighting a candle;

(5) Visual perception was tested by use of 10 abstract figures in several levels of difficulty, each of them displayed for 10 seconds, soon after which the patient would have to point to it among 4 other figures (scored as hit-or-miss) ${ }^{17}$;

(6) Phonemic perception was tested through repetition of 11 different letters or phonemes: O, A, M, P, B, D, T, L, N, G (guê), $\mathrm{Q}^{18}$;

(7) Evaluation of language and speech was carried out by way of the following query:

(7.1) Free analysis of spontaneous speech starting with the inquiries "How are you ?", "Tell me about your work!", "Tell me about your everyday activities!", paying special attention to muteness, poorness of speech, latency for response, coherence of response, comprehension impairment, phonemic or semantic paraphasias, neologisms, perseveration or echolalia, and grammatical errors (aggramatism);

(7.2) Evaluation of fluency, considering the effort to respond, latency of response, articulatory difficulties, phonetic mistakes and word-finding difficulty;

(7.3) Study of comprehension with 3 simple yes-or-no questions ("Is this place your home ?", "Is the ant bigger than the elephant ?", "Is your father's brother your uncle ?") and 3 commands ("Show me your tongue!", "Raise your arms!", "Put your hand on my nose!"); 
(7.4) Repetition of 4 words ("casa", "banana", "floresta", "metalúrgico") and 3 sentences ("Hoje não está chovendo", "A lua brilha no céu", "De grão em grão a galinha enche o papo");

(7.5) Naming 6 simple objects (a button, a coin, a clock, a pen, a match, a nail);

(7.6) Study of automatic speech by counting from 1 to 20 , mentioning the 7 days of the week, and singing the song "Happy birthday ..." in its completeness;

(7.7) Evaluation of ideomotor praxis (putting the tongue between the upper lip and the teeth, whistling, waving goodbye, pretending to light and put out the fire of a match) and constructional praxis (copying 2 match-made figures, one of them with 4 matches resembling a triangle with an adjacent line, and the other with 9 matches resembling two united pentagons).

Criteria for diagnosis of aphasia subtypes were in accordance to Hills'. On the other hand, dysarthria was defined as a disturbance of speech articulation in regard to range, rate, strength or timing of movements of the lips, tongue, palate, jaw, respiratory muscles or vocal folds, while apraxia of speech refers to a motor speech programming disorder resulting in prosody disruption, as well as distortions, substitutions, omissions and additions of phonemes, which may occur in the absence of significant weakness ${ }^{1,19}$. In case of apraxia of speech, patients are usually aware of their mistakes while struggling to correct them, but diagnosis is difficult, for this specific disturbance usually cooccurs with motor aphasia alone or in combination with other signs of linguistic impairment ${ }^{19}$.

All survivors were followed for a period of 3-15 months after the acute stroke (some of them were lost earlier in the process, but most are still enrolled in ambulatory evaluations at the Department of Neurology). Therefore, we decided to consider as "improved" all surviving patients who evolved without any signs of aphasia or dysarthria 3 months after the stroke.
Patients were not randomized for presence or absence of participation on speech or language rehabilitation therapy for the following reasons: first of all, because most of them were not receiving such treatment yet at the 3-month initial period; and second, because there is still great controversy on the health care literature as to the measurement of effectiveness of such treatment for vascular aphasia patients ${ }^{20}$.

In view of the sample size, we employed Fisher's exact test for comparison of categorical variables $(2 \times 2$ tables), except for tables with more than 2 column categories ( $2 \times \mathrm{k}$ tables), when chi-square was applied. For continuous measures to be ordered in two groups (improved or not improved), the Mann-Whitney test was used. The threshold of significance was set at $\mathrm{p}<0.05$.

This study is part of the research project 730/2006, approved by the Ethics Committee of the Faculty of Medical Sciences, University of Campinas - UNICAMP (CAAE 2081.0.000.146-06) on March 2007. All patients or their representatives signed the Informed Consent Form before the evaluation (we secured the assent of the next-of-kin if the patient could not write or had severe comprehension impairment). All the approached subjects agreed to participate.

\section{RESULTS}

Among the 37 patients included in the study (Table 1), speech or language disabilities were found in 33 (89.2\%) in the acute phase. Twenty-five of them had left hemisphere (LH) strokes, and eight had right hemisphere (RH) strokes. Overall, 29 patients survived (78.4\%) for more than 45 days after the acute brain injury (Table 2). Patients with thalamic aphasia, mixed transcortical aphasia, or motor aphasia had an excellent improvement after 1 month, but one patient with Broca's aphasia who had a larger lesion maintained his fluency impaired for 4 months after the cerebrovascular accident. Among the 6 global apha-

Table 1. General characteristics of the studied patients.

\begin{tabular}{lcc}
\hline Analyzed characteristics in the studied periods & Acute stroke & 3-month period \\
\hline $\mathrm{n}$ & 37 & 29 \\
Male gender (\%) & $22(59.4 \%)$ & $16(55.2 \%)$ \\
Female gender (\%) & $15(40.6 \%)$ & $13(44.8 \%)$ \\
Mean age in years \pm SD (SEM) & $63.96 \pm 11.30(1.86)$ & $62.12 \pm 11.03(2.05)$ \\
Mean years of schooling \pm SD (SEM) & $4.78 \pm 4.13(0.68)$ & $4.86 \pm 4.02(0.75)$ \\
Overall presence of speech or language disabilities & $33(89.2 \%)$ & $26(89.7 \%)$ \\
Left hemisphere strokes in the aphasic/dysarthric patients & $25(75.8 \%)$ & $19(73.1 \%)$ \\
Right hemisphere strokes in the aphasic/dysarthric patients & $8(24.2 \%)$ & $7(26.9 \%)$ \\
Overall survival for more than 45 days after the stroke & $29(78.4 \%)$ & $29(100.0 \%)$ \\
Presence of aphasia in the survivors & $14(48.3 \%)$ & $9(31.0 \%)$ \\
Presence of lone cortical dysarthria in the survivors & $12(41.4 \%)$ & $10(34.5 \%)$ \\
Survivors without speech or language disabilities & $3(10.3 \%)$ & $10(34.5 \%)$ \\
\hline
\end{tabular}

SD: standard deviation; SEM: standard error of the mean. 
Table 2. Characteristics of the 29 survivors.

\begin{tabular}{|c|c|c|c|c|c|c|c|}
\hline Type of disturbance & Patient & Gender & $\begin{array}{c}\text { Age } \\
\text { (years) }\end{array}$ & $\begin{array}{c}\text { Schooling } \\
\text { (years) }\end{array}$ & Lesion aspect & Neurological exam & Neurological evolution \\
\hline \multirow[t]{12}{*}{$\begin{array}{l}\text { Lone cortical } \\
\text { dysarthria }(n=12)\end{array}$} & 1 & M & 61.65 & 4 & $\begin{array}{l}\text { - small subcortical left } \\
\text { capsule-nuclear }\end{array}$ & $\begin{array}{l}\text { - hemianopia, hemiparesis, } \\
\text { hypoesthesia }\end{array}$ & $\begin{array}{l}\text { - no dysarthria } \\
\text { at } 3 \text { months }\end{array}$ \\
\hline & 2 & $\mathrm{~F}$ & 56.38 & 3 & $\begin{array}{l}\text { - small subcortical left } \\
\text { capsule-nuclear }\end{array}$ & - hemiparesis, hypoesthesia & $\begin{array}{l}\text { - no dysarthria } \\
\text { at } 5 \text { months }\end{array}$ \\
\hline & 3 & $\mathrm{~F}$ & 65.50 & 0 & $\begin{array}{l}\text { - small subcortical left } \\
\text { capsule-nuclear }\end{array}$ & - hemiparesis & $\begin{array}{l}\text { - no dysarthria } \\
\text { at } 6 \text { months }\end{array}$ \\
\hline & 4 & $\mathrm{~F}$ & 67.84 & 11 & $\begin{array}{l}\text { - large subcortical left } \\
\text { capsule-nuclear }\end{array}$ & - hemiparesis & $\begin{array}{l}\text { - less dysarthric at } \\
1 \text { month and later }\end{array}$ \\
\hline & 5 & $\mathrm{~F}$ & 73.31 & 4 & $\begin{array}{l}\text { - large subcortical left } \\
\text { capsule-nuclear }\end{array}$ & - hemiparesis, hypoesthesia & $\begin{array}{l}\text { - less dysarthric at } \\
1 \text { month and later }\end{array}$ \\
\hline & 6 & $\mathrm{~F}$ & 39.34 & 4 & $\begin{array}{l}\text { - large cortico-subcortical } \\
\text { right MCA territory }\end{array}$ & $\begin{array}{l}\text { - neglect, hemianopia, } \\
\text { hemiparesis, hypoesthesia }\end{array}$ & $\begin{array}{l}\text { - no dysarthria } \\
\text { at } 2 \text { months }\end{array}$ \\
\hline & 7 & M & 65.07 & 0 & $\begin{array}{l}\text { - small subcortical } \\
\text { right capsule-nuclear }\end{array}$ & $\begin{array}{l}\text { • neglect, hemiparesis, } \\
\text { hypoesthesia }\end{array}$ & $\begin{array}{l}\text { - less dysarthric at } \\
1 \text { month and later }\end{array}$ \\
\hline & 8 & M & 55.65 & 8 & $\begin{array}{l}\text { - large cortico-subcortical } \\
\text { right temporal-parietal }\end{array}$ & $\begin{array}{l}\text { - neglect, hemianopia, } \\
\text { hemiparesis }\end{array}$ & $\begin{array}{l}\text { - less dysarthric at } 2 \\
\text { months and later }\end{array}$ \\
\hline & 9 & M & 73.97 & 3 & $\begin{array}{l}\text { - large cortico-subcortical } \\
\text { right MCA territory }\end{array}$ & $\begin{array}{l}\text { - neglect, hemianopia, } \\
\text { hemiparesis, hypoesthesia }\end{array}$ & $\begin{array}{l}\text { - less dysarthric at } 2 \\
\text { months and later }\end{array}$ \\
\hline & 10 & M & 58.72 & 2 & $\begin{array}{l}\text { - large cortico-subcortical } \\
\text { right MCA territory }\end{array}$ & $\begin{array}{l}\text { - neglect, hemianopia, } \\
\text { hemiparesis, hypoesthesia }\end{array}$ & $\begin{array}{l}\text { - less dysarthric at } 4 \\
\text { months and later }\end{array}$ \\
\hline & 11 & $\mathrm{~F}$ & 61.19 & 2 & $\begin{array}{l}\text { - large cortico-subcortical } \\
\text { right MCA territory }\end{array}$ & $\begin{array}{l}\text { •neglect, hemianopia, } \\
\text { hemiparesis }\end{array}$ & - did not ameliorate \\
\hline & 12 & M & 72.42 & 0 & $\begin{array}{l}\text { - large subcortical right } \\
\text { capsule-nuclear }\end{array}$ & $\begin{array}{l}\text { - neglect, hemianopia, } \\
\text { hemiparesis, hypoesthesia }\end{array}$ & - did not ameliorate \\
\hline \multirow[t]{6}{*}{ Global aphasia $(n=6)$} & 13 & $\mathrm{~F}$ & 52.17 & 4 & $\begin{array}{l}\text { - large cortico- } \\
\text { subcortical left frontal }\end{array}$ & - hemianopia, hemiparesis & $\begin{array}{l}\bullet \text { no aphasia at } \\
11 \text { months }\end{array}$ \\
\hline & 14 & M & 53.35 & 7 & $\begin{array}{l}\text { - large cortico-subcortical } \\
\text { left MCA territory }\end{array}$ & - hemianopia & $\begin{array}{l}\text { - transcortical motor } \\
\text { aphasia at } 1 \text { month }\end{array}$ \\
\hline & 15 & M & 57.61 & 8 & $\begin{array}{l}\text { - large cortico- } \\
\text { subcortical left frontal }\end{array}$ & - hemiparesis & $\begin{array}{l}\text { - transcortical motor } \\
\text { aphasia at } 2 \text { months }\end{array}$ \\
\hline & 16 & $\mathrm{~F}$ & 51.31 & 16 & $\begin{array}{l}\text { - large cortico-subcortical } \\
\text { left MCA territory }\end{array}$ & $\begin{array}{l}\text { - hemianopia, hemiparesis, } \\
\text { hypoesthesia }\end{array}$ & $\begin{array}{l}\text { - motor aphasia } \\
\text { at } 1 \text { month }\end{array}$ \\
\hline & 17 & M & 46.50 & 8 & $\begin{array}{l}\text { - large cortical left } \\
\text { MCA territory }\end{array}$ & $\begin{array}{l}\text { - hemianopia, hemiparesis, } \\
\text { hypoesthesia }\end{array}$ & $\begin{array}{l}\text { - motor aphasia } \\
\text { at } 1 \text { month }\end{array}$ \\
\hline & 18 & M & 80.23 & 4 & $\begin{array}{l}\text { - large cortico-subcortical } \\
\text { left MCA territory }\end{array}$ & - hemianopia, hemiparesis & - did not ameliorate \\
\hline \multirow[t]{3}{*}{$\begin{array}{l}\text { Broca's aphasia } \\
(n=3)\end{array}$} & 19 & $\mathrm{~F}$ & 46.88 & 2 & $\begin{array}{l}\text { - small cortico- } \\
\text { subcortical left frontal }\end{array}$ & - hemianopia, hemiparesis & - no aphasia at 1 month \\
\hline & 20 & M & 70.00 & 4 & - large cortical left frontal & & - no aphasia at 1 month \\
\hline & 21 & M & 79.19 & 1 & $\begin{array}{l}\text { - large cortico- } \\
\text { subcortical left frontal }\end{array}$ & - hemianopia & $\begin{array}{l}- \text { no aphasia at } \\
4 \text { months }\end{array}$ \\
\hline \multirow[t]{2}{*}{$\begin{array}{l}\text { Wernicke's } \\
\text { aphasia }(n=2)\end{array}$} & 22 & $\mathrm{~F}$ & 71.26 & 4 & $\begin{array}{l}\text { - small cortico-subcortical } \\
\text { left temporal-parietal }\end{array}$ & - hemianopia & $\begin{array}{l}\text { - transcortical sensory } \\
\text { aphasia at } 1 \text { month }\end{array}$ \\
\hline & 23 & M & 58.67 & 16 & $\begin{array}{l}\text { - small cortical left } \\
\text { temporal-parietal }\end{array}$ & & $\begin{array}{l}\cdot \text { no aphasia at } \\
3 \text { months }\end{array}$ \\
\hline $\begin{array}{l}\text { Mixed Transcortical } \\
\text { aphasia }(n=1)\end{array}$ & 24 & M & 74.14 & 3 & $\begin{array}{l}\text { - large subcortical left } \\
\text { temporal-parietal }\end{array}$ & - hemiparesis & - no aphasia at 1 month \\
\hline $\begin{array}{l}\text { Transcortical Motor } \\
\text { aphasia }(n=1)\end{array}$ & 25 & $\mathrm{~F}$ & 69.89 & 7 & $\begin{array}{l}\text { - large subcortical left } \\
\text { temporal-parietal }\end{array}$ & - hemianopia, hemiparesis & - did not ameliorate \\
\hline $\begin{array}{l}\text { Thalamic } \\
\text { aphasia (n=1) }\end{array}$ & 26 & $\mathrm{~F}$ & 80.03 & 4 & $\begin{array}{l}\text { - small subcortical } \\
\text { left temporal-parietal } \\
\text { (capsule-thalamic) }\end{array}$ & $\begin{array}{l}\text { - hemiparesis, } \\
\text { hypoesthesia }\end{array}$ & - no aphasia at 1 month \\
\hline \multirow[t]{3}{*}{$\begin{array}{l}\text { No aphasia or } \\
\text { dysarthria }(n=3)\end{array}$} & 27 & $\mathrm{~F}$ & 53.15 & 4 & $\begin{array}{l}\text { - small subcortical } \\
\text { right parietal }\end{array}$ & $\begin{array}{l}\text { - hemianopia, hemiparesis, } \\
\text { hypoesthesia }\end{array}$ & \\
\hline & 28 & M & 52.87 & 4 & $\begin{array}{l}\text { - small subcortical } \\
\text { left parietal }\end{array}$ & $\begin{array}{l}\text { • hemiparesis, } \\
\text { hypoesthesia }\end{array}$ & \\
\hline & 29 & M & 63.32 & 4 & $\begin{array}{l}\text { - small subcortical } \\
\text { left parietal }\end{array}$ & - hemianopia, hemiparesis & \\
\hline
\end{tabular}

MCA: middle cerebral artery; F: female; M: male; for lesion size - large: more than $1.5 \mathrm{~cm}$ in diameter on CT or 2T-MR at any plane; small: less than 1.5 $\mathrm{cm}$ in diameter on CT or 2T-MR at all planes; "survivors": patients who survived for more than 45 days after the acute stroke. 


\begin{tabular}{lcc}
\hline Investigated factor & $\begin{array}{c}\text { p-value } \\
\text { (group of 29 survivors) }\end{array}$ & $\begin{array}{c}\text { p-value } \\
\text { (group of 26 survivors) }\end{array}$ \\
\hline Gender (male, female)* & - & 0.999 \\
Age** $^{*}$ & - & 0.931 \\
Schooling** $^{*}$ & - & 0.814 \\
Type of speech/language disturbance*** & - & 0.072 \\
Brain infarct side (left, right)* & 0.675 & 0.629 \\
Brain infarct size (small, large)* & 0.017 & 0.149 \\
Lesion type by structural organization*** & 0.071 & 0.189 \\
Brain injury topography*** & - & 0.324 \\
\hline
\end{tabular}

Short-term refers to the first 3 months post-stroke, comparing groups of improved patients with non-improved ones; "improvement": no signs of aphasia or dysarthria 3 months after the acute stroke; for groups - group of 29 survivors includes all patients who survived for more than 45 days after the acute stroke, while group of 26 survivors includes all patients who survived for more than 45 days but presented with aphasia or dysarthria at the acute stroke phase; for lesion size - large: more than $1.5 \mathrm{~cm}$ in diameter on CT or 2T-MR at any plane, small: less than $1.5 \mathrm{~cm}$ in diameter on CT or 2T-MR at all planes; structural organization of lesion refers to cortical involvement, subcortical involvement, or both; brain injury topography refers to frontal, temporal-parietal, capsule-nuclear or full middle cerebral artery territory; *Fisher's exact test; ${ }^{* *}$ Mann-Whitney test; ${ }^{* * *}$ chi-square test.

sia patients, one did not improve, two evolved with motor aphasia after 1 month, two evolved with transcortical motor aphasia after 1-2 months, and one had no aphasia after 11 months (after evolving from motor aphasia upon 1 month to transcortical motor aphasia upon 6 months). Among the 12 lone cortical dysarthria patients, four evolved without dysarthria after 2-6 months, six were less dysarthric after 1-6 months, and two (with larger lesions) maintained their earlier impairment.

Among the surviving patients, large infarcts were found in all global aphasia and transcortical aphasia patients. Criteria for small infarcts were met in patients who had no aphasia or dysarthria, Wernicke's aphasia and thalamic aphasia patients. Patients with Broca's aphasia and lone cortical dysarthria were found to have either small or large size brain infarcts. All 3 patients who showed no signs of speech or language disorders from the start had lesions exclusively in parietal lobes.

Taking into account the fact that all patients suffered a single first-ever brain infarction, statistical analysis showed only one significant result for prognosis ( $\mathrm{Ta}$ ble 3): regardless of the presence or absence of speech or language disorders in the acute phase, patients who survived had lesser chances of portraying aphasia or dysarthria 3 months after the stroke if the infarct size was small $(n=29 ; p=0.017)$. All other investigated factors proved to be non-significant in our sample.

In regard to the type of speech or language disturbance presented in the acute stroke phase, we also analyzed if a specific form of aphasia could bring a better prognosis for language evolution. This calculus involved only the 14 patients who presented with aphasia in the acute phase and survived for more than 45 days, excluding patients with lone cortical dysarthria, but the results were also non-significant $(p=0.112)$.

At the end of the 3-month period, the frequencies of speech or language disorders among the 29 survivors were: 10 without aphasia or dysarthria, 10 with lone cortical dysarthria, 4 with Broca's aphasia, 3 with transcortical motor aphasia, one with transcortical sensory aphasia and one with global aphasia. All patients who survived for more than 45 days after the stroke were still alive at the end of the 3-month period. Among the deceased patients, six were aphasic and dysarthric, one had a lone cortical dysarthria, and only one had no speech or language impairment.

\section{DISCUSSION}

Our statistical analysis demonstrated that patients who suffered a single first-ever brain infarction and survived had lesser chances of presenting with aphasia or dysarthria 3 months after the stroke if the infarct size was small. This result included patients who presented without dysarthria or aphasia from the start.

Some factors that have been implied as determinants for speech and language performance include age and education $^{21}$. Earlier studies demonstrated that other factors carry a prognostic power in terms of speech and language evolution after a first stroke, such as brain injury side ${ }^{2,22}$ and topography in terms of cortical and/or subcortical 
involvement ${ }^{22,23}$. When patients present with cerebrovascular subcortical injuries, prognosis is much more favorable the less likely one is to find that there has been cortical hypoperfusion, which has been verified in studies with ${ }^{133} \mathrm{Xe}-\mathrm{rCBF}$ (regional cerebral blood flow) methods ${ }^{24}$ and perfusion $\mathrm{MR}^{23}$. It is believed that recovery of language is caused primarily by arterial recanalization or expansion of collaterals, giving rise to an enhanced flow in the hypoperfused cortical penumbra ${ }^{24}$. One should also note that our study showed marginally significant results that favored a better evolution of speech and language in the short term for patients with exclusively subcortical lesions ( $n=29 ; p=0.071)$, regardless of the presence of aphasia or dysarthria in the acute stroke phase. In spite of these records, save for infarct size, no other factors which were studied in our work (gender, age, schooling, type of speech or language disorder, brain injury side and topography in the categories of specific sites and structural organization) displayed significant results in terms of speech and language short-term prognosis, but this information should be confirmed in studies with larger samples.

The proportions of aphasia subtypes we found were not different from those found in other studies ${ }^{12,13}$, except for our smaller variety (none of the evaluated patients met the established criteria for conduction aphasia, semantic aphasia, non-thalamic subcortical aphasia, apraxia of speech or verbal deafness). This could be due to the size of our sample, but one must consider that only firststroke patients were included in our work.

The time-window used for subject evaluation in this study (72 hours post-stroke) was adequate, since many acute phase stroke patients are not able to display the necessary strength or disposition to cooperate in the language inquiries. The ones who could not be promptly evaluated were assessed one or two days later, allowing for the testing of a greater number of individuals.

Aphasia is one of the most important factors to jeopardize acute stroke diagnosis ${ }^{25}$; the already described catastrophic reaction ${ }^{26}$, more frequent in aphasic acute stroke patients, was also assessed in our subjects. Nevertheless, even in face of the difficulties pertaining to the evaluation of acute stroke patients, there were no cases of catastrophic reaction in our sample.

Classic clinical-anatomic correlations were found pertaining brain injury topography in relation to the aphasia subtype presented by each subject ${ }^{11}$. Chronic phase neuroimaging appraisal was important for correct anatomical analysis.

Most patients with aphasia changed to a less intense form of language impairment during follow-up, as expected ${ }^{12,13}$. A nonfluent aphasia could evolve into a fluent form of aphasia, whereas the opposite never occurred. In the long term, it is difficult to assess how much of this result can be attributed to a natural evolution or to interventional therapies ${ }^{3}$.

None of the global aphasia patients showed a good language impairment resolution in the 3-month period, and most persisted with a predominant loss of fluency. Dysarthric patients also evolved in a slow pace as to their speech performance. Wernicke's aphasia patients had a good evolution in our sample, but this could be due to the small number of subjects and the small lesion sizes they presented. Subjects with predominance of motor compromise had a good evolution.

None of our patients received specific pharmacological treatment for the language impairment. In our view, the data yet available on its efficacy is still controversial ${ }^{1,27}$, and a greater number of randomized clinical trials is needed to support such therapy.

Short-term mortality was higher for aphasics than for patients with no language impairment, in accordance with other authors ${ }^{12}$. Some studies have shown that longterm mortality is also correlated with the presence of aphasia, ${ }^{3,12}$

In conclusion, global aphasia and lone cortical dysarthria carried a worse prognosis for speech and language evolution. Size of brain lesion seemed to be the most influential factor for neurological outcome at 3 months post-stroke.

\section{REFERENCES}

1. Hillis AE. Aphasia: progress in the last quarter of a century. Neurology 2007;69:200-213.

2. Karbe H, Thiel A, Weber-Luxenburger G, Herholz K, Kessler J, Heiss WD. Brain plasticity in poststroke aphasia: what is the contribution of the right hemisphere? Brain Lang 1998;64:215-230.

3. Bakheit AMO, Shaw S, Carrington S, Griffiths S. The rate and extent of improvement with therapy from the different types of aphasia in the first year after stroke. Clin Rehabil 2007;21:941-949.

4. Lezak MD, Howieson DB, Loring DW. Neuropsychological Assessment. $4^{\text {th }}$ Ed. New York: Oxford University Press, 2004.

5. Wee JYM, Hopman WM. Stroke impairment predictors of discharge function, length of stay, and discharge destination in stroke rehabilitation. Am J Phys Med Rehabil 2005;84:604-612.

6. Ferreira RGF, Santos LCC, Silva ASS, Faria ES. A filogênese da linguagem: novas abordagens de antigas questões. Arq Neuropsiquiatr 2000;58:188-194.

7. Hilari K, Byng S, Lamping DL, Smith SC. Stroke and aphasia quality of life scale-39 (SAQOL-39): evaluation of acceptability, reliability, and validity. Stroke 2003;34:1944-1950.

8. Williams LS, Weinberger M, Harris LE, Clark DO, Biller J. Development of a stroke-specific quality of life scale. Stroke 1999;30:1362-1369.

9. Daviet JC, Verdié-Kessler C, Stuit A, et al. Facteurs prédictifs du devenir fonctionnel et du retour à domicile après un premier accident vasculaire cérébral hémisphérique. Ann Readapt Med Phys 2006;49:49-56.

10. Weir CJ, Bradford APJ, Lees KR. The prognostic value of the components of the Glasgow Coma Scale following acute stroke. QJ Med 2003; 96:67-74. 
11. Kreisler A, Godefroy O, Delmaire C, et al. The anatomy of aphasia revisited. Neurology 2000;54:1117-1123.

12. Laska AC, Hellblom A, Murray V, Kahan T, von Arbin M. Aphasia in acute stroke and relation to outcome. J Intern Med 2001;249:413-422.

13. Pedersen PM, Vinter K, Olsen TS. Aphasia after stroke: type, severity and prognosis. The Copenhagen aphasia study. Cerebrovasc Dis 2004; 17:35-43.

14. Adams HP, Bendixen BH, Kappelle LJ, et al. Classification of subtype of acute ischemic stroke: definitions for use in a multicenter clinical trial. Stroke 1993;24:35-41.

15. Strub RL, Black FW. The mental status examination in neurology. $4^{\text {th }}$ Ed. Philadelphia: Davis, 2000.

16. Oldfield RC. The assessment and analysis of handedness. The Edinburgh Inventory. Neuropsychologia 1971;9:97-113.

17. Jones-Gotman M, Zatorre RJ, Olivier A, et al. Learning and retention of words and designs following excision from medial or lateral temporallobe structures. Neuropsychologia 1997;35:963-973.

18. Christensen AL. Luria's neuropsychological investigation. $2^{\text {nd }}$ edition. Copenhagen: Munksgaard, 1979.

19. Ogar J, Willock S, Baldo J, Wilkins D, Ludy C, Dronkers N. Clinical and anatomical correlates of apraxia of speech. Brain Lang 2006;97:343-350.

20. Cappa SF, Benke T, Clarke S, Rossi B, Stemmer B, Van Heugten CM
EFNS guidelines on cognitive rehabilitation: report of an EFNS task force. Eur J Neurol 2005;12:665-680.

21. Mansur LL, Radanovic M, Taquemori L, Greco L, Araújo GC. A study of the abilities in oral language comprehension of the Boston Diagnostic Aphasia Examination - Portuguese version: a reference guide for the Brazilian population. Braz J Med Biol Res 2005;38:277-292.

22. Reineck LA, Agarwal S, Hillis AE. "Diffusion-clinical mismatch" is associated with potential for early recovery of aphasia. Neurology 2005; 64:828-833.

23. Hillis AE, Wityk RJ, Barker PB, et al. Subcortical aphasia and neglect in acute stroke: the role of cortical hypoperfusion. Brain 2002;125: 1094-1104.

24. Olsen S, Bruhn P, Öberg RGE. Cortical hypoperfusion as a possible cause of "subcortical aphasia". Brain 1986;109:393-410.

25. Hand PJ, Haisma JA, Kwan J, et al. Interobserver agreement for the bedside clinical assessment of suspected stroke. Stroke 2006;37:776-780.

26. Carota A, Rossetti AO, Karapanayiotides T, Bogousslavsky J. Catastrophic reaction in acute stroke: a reflex behavior in aphasic patients. Neurology 2001;57:1902-1905.

27. Korsukewitz C, Breitenstein C, Schomacher M, Knecht S. Pharmakologische Zusatzbehandlung in der Aphasietherapie: Status quo und Perspektiven. Nervenarzt 2006;77:403-415. 